Kababish called them to the writer) are the surviving representatives of the old Nuba population of the hills of northern Kordofan, the remains of whose houses can be seen on so many hills. In spite of the contemptuous tone taken by the nomad Arabs when speaking of these folk, they are bold raiders, and do not hesitate to cross the border to lift the cattle and camels of even the strongest tribes, the herdsmen of which they kill or enslave as opportunity offers.

The Zaghawa are Hamiticised negroids who about the end of the eighteenth century emerged as a vassal State in northern Darfur under practically independent rulers. It was probably about this time, or a little earlier, that a party of Zaghawa migrated eastwards and seized the hills in the neighbourhood of Jebel Kagmar in northern Kordofan, where they settled and which their descendants still occupy, though none of these can speak a word of any langilage but Arabic, and have adopted a pedigree dating back nineteen generations to Khalid el Guhani, the brother of Abdulla el Guhani, to whom the usual faked nisba of the tribes of the northern Sudan goes back.

The mere mention of these two matters will serve to give some idea of the value and scope of the book.

\section{A MEMORIAL TO SIR JOSEPH HOOKER.}

A MEMORIAL to the late Sir J. D. Hooker, at Kew, near the similar memorial to his father, Sir W. J. Hooker, was unveiled by Lady Hooker in the presence of members of the Hooker family on Saturday, February 22. The memorial consists of a mural tablet of coloured marble bearing the following inscription :--

I 8I7-I9II JOSEPH DALTON HOOKER, O.M. G.C.S.I. C.B. M.D. D.C.L. LL.D., ASSOCIÉ ÉTRANGER OF THE INSTITUTE OF FRANCE, KNIGHT OF THE PRUSSIAN ORDER “POUR LE MÉRITE," SOMETIME PRESIDENT OF THE ROYAL SOCIETY, FOR XX YEARS DIRECTOR OF THE ROYAL BOTANIC GARDENS KEW. BORN AT HALESWORTH 3OTH JUNE I $8 I_{7} 7$, DIED AT WINDLESHAM IOTII DEC. IGII. THE WORKS OF THE LORD ARE GREAT SOUGHT OUT OF ALL THEM THAT HAVE PLEASURE THEREIN.

Below this inscription is a Wedgwood medallion portrait of Sir Joseph, flanked and supported by five panels containing Wedgwood figures of plants with which, in the course of his long career, there had grown up some especial association. In the upper and corner panels, left and right, these plants are an Aristolochia, commemorating his connection with African floristic work and travel, and a Nepenthes, recalling a notable contribution to our knowledge of vegetable morphology and physiology. The left lower corner panel contains a Cinchona, commemorating Hooker's connection with one of the most humane episodes in economic botany during his lifetimethe introduction to south-eastern Asia of the medicinal Cinchonas of South America. The panel which balances this on the right contains a
Rhododendron, commemorative of Hooker's great Himalayan journey.

In a smaller central panel between the lower corner ones is a Celmisia, recalling the southern voyage with Ross and the labour bestowed on the flora of New Zealand. At foot are the family arms with the family motto and the motto of the Most Exalted Order of the Indian Empire, of which Hooker was a member in the highest grade. The portrait, a head profile to left, is the work of Mr. Frank Bowcher, and is an excellent likeness, recalling the same artist's treatment of his subject in the medallion executed in 1898 at the instance of the President and Council of the Linnean Society to record the completion of Hooker's "Flora of British India" and his sixty years' services to science.

\section{SIR WILLIAM HENRY WHITE, K.C.B., F.R.S.}

BY the sudden death of sir William White on February 27, at sixty-eight years of age, the country has lost one of her best sons and engineering science one of its leading authorities. Sir William White was born at Devonport in 1845 , and started his professional life by leaving a private school in the town, in which he was at the time "head boy," and becoming a shipwright's apprentice in Devonport Dockyard.

In the fullest sense of the term the boy was "father to the man," as on entering the dockyard he occupied the highest position among those entering with him, a position which he not only maintained but improved upon by rapidly becoming higher than apprentices who had been entered before him and had had longer practical training and longer education in the dockyard school.

In 1864 a Royal School of Naval Architecture and Marine Engineering was founded at South Kensington, and to this eight shipwright apprentices were appointed, of whom Sir William was the first in order of merit. Of these only one, viz. Mr. H. E. Deadman, C. B., who was principal assistant to Sir William on his retirement from Admiralty service, now survives.

During his study at South Kensington Sir William uniformly kept highest in order of merit, and although some of his college mates, notably the late Dr. F. Elgar, formerly Director of dockyard work at the Admiralty, Mr. W. John, of Lloyd's Register, Mr. W. J. Bone, of Newcastle, and $\mathrm{Mr}$. H. E. Deadman, mentioned above, achieved great distinction, it fell to the lot of Sir William to be called upon to undertake still higher work, and this work he carried out most successfully under trying conditions, often involving shortness of Admiralty staff and inadequacy of office accommodation.

On completing, in 1867 , his training at South Kensington, Sir William joined the Admiralty Constructive Staff, under the headship of Sir Edward Reed, K.C.B., and at once threw himself with his characteristic zeal into all of the many difficult matters existing at that time of changing

NO. 2262, VOL. 9I] 